\title{
Students' Mathematical Thinking and Comprehensive Mathematics Instruction (CMI) Model
}

\author{
Nita Delima ${ }^{1, *)}$, Yaya S. Kusumah ${ }^{2}$, Siti Fatimah ${ }^{2}$ \\ ${ }^{1}$ Universitas Subang, Indonesia \\ ${ }^{2}$ Universitas Pendidikan Indonesia, Indonesia
}

\author{
Received: November 8, 2020 \\ Revised: February 24, 2021 \\ Accepted: May 13, 2021
}

\begin{abstract}
Several facts about learning mathematics in high school show that students' mathematical thinking skills are still low. Therefore, it is a need to increase these variables, considering that they are very important in supporting students' academic achievement. This study discusses the application of a comprehensive mathematics instruction (CMI) model in mathematics learning as an effort to improve students' mathematical thinking. This current research was a quasi-experimental research. The sample was taken purposively from the population of high school students in Subang Regency, West Java, Indonesia. The instruments used in the research consisted of a mathematical thinking ability test and an observation sheet. Mathematical thinking ability is built by four important aspects, namely specializing, generalizing, conjecturing, and convincing. The CMI model is a learning model that accommodates three stages, namely develop, solidify, and practice. Each of these stages provides the opportunity for students to develop specializing, generalizing, conjecturing, and convincing aspects. The results showed that the CMI model can improve students' mathematical thinking abilities. Thus, the CMI model deserves to be used as an innovation in mathematics learning.
\end{abstract}

Keywords: CMI model, mathematical thinking

(*) Corresponding Author: $\quad$ nitadelima1985@gmail.com

How to Cite: Delima, N., Kusumah, Y.S., \& Fatimah, S. (2021). Students' mathematical thinking and comprehensive mathematics instruction (cmi) model. Formatif: Jurnal Ilmiah Pendidikan MIPA, 11 (2): 161-172. http://dx.doi.org/10.30998/formatif.v11i2.7807

\section{INTRODUCTION}

Mathematical thinking is an ability that must be possessed by students because this ability can support mastery of other fields of science outside mathematics. The vision recommended by the National Council of Teachers of Mathematics (NCTM) is that in every mathematics learning, students can confidently have a sense of attachment to complex mathematical tasks chosen by the teacher, while the teacher should help students in creating, refining and exploring conjectures in such a way that they can convince themselves of the truth of the conjecture itself (Hendrickson et al., 2013). In this case, it can be said that NCTM indirectly recommends mastery of mathematical thinking in every lesson.

Basically, mathematical thinking is the ability to think dynamically, which can add to the complexity of our mathematical ideas and can expand our understanding of mathematics. The mathematical thinking ability can be viewed as a way of seeing something, underlining it in numerical form, structure or logic essence and analyzing patterns according to it (Devlin, 2012). Mason \& Johnston-Wilder (2004) argue that mathematical thinking is the process and action of mathematicians when they work on mathematical problems which include exemplifying, specializing, completing, deleting, 
correcting, comparing, sorting, organizing, changing, varying, reversing, altering, generalizing, conjecturing, explaining, justifying, verifying, convincing, refuting. Mason et al. (2010) argued that there are four important processes in mathematical thinking, namely specializing, generalizing, conjecturing, and convincing.

Stacey (2006) states that the framework used by PISA to measure mathematical literacy includes several components contained in mathematical thinking abilities, such as components of reasoning, modeling, and making connections between ideas. Based on the PISA results 2018, the math literacy score of Indonesian students is 379 which is under the average score of OECD member (OECD, 2019). Because the problem framework provided by PISA includes several components in mathematical thinking abilities, it can be said that Indonesian students' mathematical thinking skills are still low. This is reinforced by the results of the 2019 National Examination which show that students still have difficulty working on higher order thinking problems (Kemendikbud, 2019). In addition, based on the observations of researchers on several high school students in Subang, West Java, data was obtained that the majority of high school students experienced difficulties when faced with problems related to the application of mathematics in everyday life, students were accustomed to routine questions, trapped in arithmetic activities and a standard algorithm, so that their thought process becomes rigid. In the other side, the replacement of the National Examination with the National Assessment (AN) in 2021 is an effort to equalize education in Indonesia which refers to international standardization, like PISA (Kemdikbud, 2020). Therefore, improving students' mathematical thinking abilities is one of the ways to be an effort to prepare students to face AN.

Mathematical thinking can be constructed through the formation of an appropriate learning atmosphere, such as asking questions, giving challenges and reflecting (Stacey, 2006). Delima et al. (2021) stated that the learning model that can build mathematical thinking abilities is a CMI model. It has three stages, namely develop, solidify, and practice. Each stages has a teaching cycle consisting of launch, explore and discuss (Delima, 2020). Delima \& Fitriza (2017) said that CMI model has a syntax in the form of a pedagogical strategy that can be used by teachers to guide students in building ideas, strategies, and initial mathematical representations so that can develop into a definition and properties, procedures, and mathematical models. The process of developing students' ideas, strategies and representations towards definitions and characteristics, procedures, as well as models, will involve specializing, generalizing, conjecturing, and convincing processes. So, it is suspected that CMI model can improve students' mathematical thinking abilities.

Research that has been conducted by both Delima \& Fitriza (2017) or Delima et al. (2021) is limited to discussing how to achieve students' mathematical thinking abilities through learning with the CMI model. Therefore, on this occasion, the author is interested in testing the feasibility of this model in improving mathematical thinking abilities. The objective of this study was to determine whether the increase in mathematical thinking skills of students who receive learning with the comprehensive mathematics instruction (CMI) model is better than students who receive conventional learning. In addition, to find out whether there is an interaction between learning factors and students' prior mathematical knowledge on improving mathematical thinking abilities.

\section{METHODS}

This current research was a quasi-experimental research, with a quantitative approach. This research involved three variables, namely the independent, dependent and control variables. The independent variable of this research is CMI learning model. The dependent variable is the improvement of mathematical thinking ability. The control 
variable in this study was students' mathematical prior knowledge (PAM). The research design used is the nonequivalent control group design. Cohen et al. (2007) describes the nonequivalent control group design as follows.

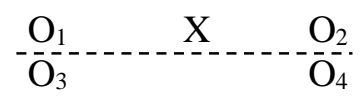

Description:

$\mathrm{X}$ : Learning with the CMI model.

$\mathrm{O}_{1}$ : Prior mathematical thinking skills before learning with the CMI model.

$\mathrm{O}_{2}$ : The final ability of mathematical thinking after being given learning with the CMI model.

$\mathrm{O}_{3}$ : Initial mathematical thinking skills before there is learning with conventional model.

$\mathrm{O}_{4}$ : The final ability of mathematical thinking after being given learning with conventional model.

The conventional model referred to a learning model commonly used in class, namely the problem-based learning model. The population of this study were all grade XI high school students in Subang, West Java, Indonesia. The selection of high school students as the population is because mathematical thinking skills can help students in dealing with national assessments. In this study, SMA N 3 Subang was designated as the sample school. The selection of control and experimental classes was carried out randomly by class, obtained by class IX IPS 3 as the experimental class and IX IPS 1 as the control class.

This study uses two types of instruments, namely a test instrument in the form of description questions to measure PAM and mathematical thinking abilities and a non-test instrument in the form of an observation sheet to observe the application of the CMI model. The results of the PAM test are used to group students into three levels of PAM, namely low, medium, and high. Grouping is done by making a test score frequency distribution table to obtain the following criteria for grouping students' PAM levels.

Table 1. PAM Levels

\begin{tabular}{lccc}
\hline \multirow{2}{*}{ Interval } & Level & \multicolumn{2}{c}{ Number of students } \\
\cline { 3 - 4 } & & CMI & Conventional \\
\hline $10 \leq$ PAM Score $<14$ & Low & 16 & 4 \\
$14 \leq$ PAM Score $<18$ & Moderate & 10 & 21 \\
$18 \leq$ PAM Score $<22$ & High & 11 & 9 \\
\hline Total & & 37 & 34 \\
\hline
\end{tabular}

The mathematical thinking ability test instrument, uses the mathematical thinking ability indicator proposed by Mason et al. (2010), namely: (a) Specializing, trying problems by looking at examples, paying attention to simple cases; (b) Generalizing, looking for patterns and relationships; (c) Conjecturing, predicting relationships and outcomes; (d) Convincing, finding and communicating the reasons why something is true. The increase in mathematical thinking ability is measured using the following $\mathrm{N}$-gain score (Hake, 1999).

$$
N-\text { gain }=\frac{\text { Posttest }- \text { Pretest }}{100-\text { Pretest }}
$$

The categorization of N-gain scores follows Hake's rule (Hake, 1999) shown table 2. 
Table 2. The categorization of N-gain scores

\begin{tabular}{ll}
\hline Score & Category \\
\hline $\mathrm{N}$-gain $\leq 0,30$ & Low \\
$0,30<\mathrm{N}$-gain $\leq 0,70$ & Medium \\
$\mathrm{N}$-gain $>0,70$ & High \\
\hline
\end{tabular}

The interactions between the variables studied were analyzed based on the following factorial designs:

Table 3. Factorial Design of the Research

\begin{tabular}{lll}
\hline PAM & CMI & Conventional \\
\hline Low $(\mathrm{R})$ & KMTR_CMI & KMTR_KON \\
Moderate (S) & KMTS_CMI & KMTS_KON \\
High (T) & KMTT_CMI & KMTT_KON \\
\hline Total & & \\
\hline
\end{tabular}

Information :

KMTR_CMI : N-gain score of mathematical thinking ability of students with low PAM scores who use the CMI model

KMTS_CMI : The N-gain score of the mathematical thinking ability of students with moderate PAM scores and using the CMI model

KMTT_CMI : The N-gain score of mathematical thinking ability of students with high PAM scores who use the CMI model

KMTR_KON : The N-gain score of the mathematical thinking ability of students with low PAM scores and using conventional learning

KMTS_KON : The N-gain score of the mathematical thinking ability of students with moderate PAM scores and using conventional learning

KMTT_KON : Mathematical thinking ability N-gain score for students with high PAM scores and using conventional learning.

The data analysis technique used is descriptive statistics, Kolmogorov-Smirnov normality test, Levene homogeneity test, t-test, Mann-Whitney U test and the two-way ANOVA test.

\section{RESULTS \& DISCUSSION}

\section{Results}

The data on the improvement of mathematical thinking abilities are obtained from the N-gain value. The description of the N-gain data can be seen in Table 4 .

Table 4. Descriptive Statistics of Mathematical Thinking N-gain Score

\begin{tabular}{llllllll}
\hline Learning & \multirow{2}{*}{ Model } & PAM & \multicolumn{2}{c}{ N-gain } & Learning & \multirow{2}{*}{ PAM } & \multicolumn{2}{c}{ N-gain } \\
\cline { 3 - 5 } \cline { 3 - 6 } & & Mean & SD & Model & & Mean & SD \\
\hline CMI & Low & 0,586 & 0,134 & Conventional & Low & 0,417 & 0,075 \\
& Moderate & 0,627 & 0,133 & & Moderate & 0,425 & 0,127 \\
& High & 0,526 & 0,134 & & High & 0,514 & 0,107 \\
\cline { 2 - 6 } & Total & 0,579 & 0,135 & & Total & 0,447 & 0,120 \\
\hline
\end{tabular}


Based on Table 4, the mean N-gain score of students who received the CMI model learning and those who obtained the conventional model was different. However, it is necessary to do statistical testing to prove the hypothesis that there is a significant difference in the mean $\mathrm{N}$-gain score between students who receive the CMI model learning and those who receive the conventional model. Previously, a prerequisite test was conducted in the form of normality and homogeneity tests for $\mathrm{N}$-gain data based on learning factors. The results show that each data group has a normal distribution and is also homogeneous. Therefore, hypothesis testing is carried out using the t-test. A summary of the results of the t-test calculation is presented in the table 5 .

Table 5. t-test Results N-gain Score Based on Learning Model

\begin{tabular}{cccc}
\hline Learning Model & $\mathrm{t}$ & $\mathrm{df}$ & Sig. (2-tailed) \\
\hline CMI : Conventional & 4,209 & 64 & 0,000 \\
\hline
\end{tabular}

Table 5 shows that the Sig. obtained is 0.000 , then H0 is rejected. In other words, the increase in the abilities of students who received CMI model learning and those who obtained the conventional model was significantly different. In the following section, the $\mathrm{N}$-gain statistical values for each indicator are described.

Table 6. Descriptive Statistics of N-gain Score for Each Mathematical Thinking Indicator

\begin{tabular}{lcccccccc}
\hline \multirow{2}{*}{ Learning Model } & \multicolumn{2}{c}{ Specializing } & \multicolumn{2}{c}{ Generalizing } & \multicolumn{2}{c}{ Conjecturing } & \multicolumn{2}{c}{ Convincing } \\
\cline { 2 - 9 } & Mean & SD & Mean & SD & Mean & SD & Mean & SD \\
\hline CMI & 0,587 & 0,192 & 0,497 & 0,289 & 0,581 & 0,197 & 0,581 & 0,197 \\
Conventional & 0,591 & 0,105 & 0,235 & 0,307 & 0,373 & 0,221 & 0,373 & 0,221 \\
\hline
\end{tabular}

Table 6 shows that the mean $\mathrm{N}$-gain of students who get CMI model is greater than students who get conventional models, it occurs only in generalizing, conjecturing and convincing indicators. In the specializing indicator, the mean $\mathrm{N}$-gain of students who get CMI model has an average smaller than the conventional model. This indicates that the CMI model is more useful in improving generalizing, conjecturing and convincing abilities. To find out whether this difference is significant or not, a statistical test is carried out on the hypothesis which says that there is a significant difference in mean $\mathrm{N}$-gain between students obtaining the CMI model and those obtaining the conventional model, taking into account each indicator of mathematical thinking ability. However, previously, a prerequisite test was conducted in the form of a normality test. The results show that there are several data groups that do not have a normal distribution. Thus, hypothesis testing is carried out using the Mann-Whitney U. The following are the test results.

Table 7. Mann-Whitney U Test Results based on Indicator of Mathematical Thinking

\begin{tabular}{lccc}
\hline $\begin{array}{l}\text { Indicator of } \\
\text { Mathematical Thinking }\end{array}$ & Learning Model & Mann-Whitney U & $\begin{array}{c}\text { Asymp. Sig. } \\
\text { (2-tailed) }\end{array}$ \\
\hline Specializing & CMI: Conventional & 507,000 & 0,632 \\
Generalizing & CMI: Conventional & 275,500 & 0,000 \\
Conjecturing & CMI: Conventional & 270,000 & 0,000 \\
Convincing & CMI: Conventional & 270,000 & 0,000 \\
\hline
\end{tabular}

Table 7 shows that the significant differences in improving mathematical thinking abilities between students who get CMI model learning and those who get conventional 
models are found in generalizing, conjecturing and convincing indicators. Meanwhile, in the specializing indicator, there is no significant difference in improving mathematical thinking skills between students who get CMI model learning and those who get conventional models. These results indicate that the CMI model has a significant effect on improving every indicator of mathematical thinking ability, except specializing.

The next objective of this study is to determine the interaction between learning models and PAM on improving mathematical thinking abilities. However, beforehand, a statistical test was conducted on the hypothesis which said that there was a difference in the N-gain of students who obtained the CMI model and students who obtained the conventional model based on their PAM. The prerequisite test in the form of a normality test shows that there are data that are not normally distributed. Therefore, hypothesis testing was performed using the Mann-Whitney U test statistic. A summary of the test results is presented in the table 8 .

Table 8. Mann-Whitney U Test Results based on PAM

\begin{tabular}{llcc}
\hline PAM & Learning Model & Mann-Whitney U & Asymp. Sig. (2-tailed) \\
\hline Low & CMI: Conventional & 5,500 & 0,005 \\
Moderate & CMI: Conventional & 28,000 & 0,003 \\
High & CMI: Conventional & 33,500 & 0,808 \\
\hline
\end{tabular}

Table 8. shows that the Sig. value obtained in students with low PAM level is 0.005 , then $\mathrm{H} 0$ is rejected, in other words, in this group of students, the increase in mathematical thinking skills of students who get the CMI model and those who get the conventional model is significantly different. Likewise, students with the moderate PAM level had the value of Sig. equal to 0.005 , so $\mathrm{H} 0$ is rejected, in other words, in this group of students, the increase in mathematical thinking skills of students who obtained the CMI model and those who obtained the conventional model also differed significantly. Unlike students who have a high PAM category, in this group of students, there is no significant difference between the increase in mathematical thinking abilities of students who get the CMI model and those who get the conventional model. Thus, it can be concluded that the CMI model is more useful in improving the mathematical thinking abilities of students who have low and moderate prior mathematical knowledge.

The analysis of increasing mathematical thinking abilities is continued at the stage of analyzing the improvement of each indicator of students' mathematical thinking abilities based on their PAM. Below is given Table 7 which describes the student's N-gain statistics on each indicator of their mathematical thinking ability based on their PAM.

Table 9 shows that in each PAM category, the ability to generalize, conjecturing and convincing students who obtained the CMI model had a greater mean N-gain than students who obtained the conventional model. Meanwhile, in the specializing ability, students who obtained the CMI model had a greater mean N-gain than those who obtained the conventional model only in groups of students with low PAM levels. This indicates that the CMI model is more useful for increasing the generalizing, conjecturing, and convincing abilities of each student's PAM level, whereas in specializing skills, the CMI model is only useful for students with low PAM levels.

In addition, Table 9 provides information that for students with high PAM levels, the increase in generalizing, conjecturing and convincing abilities that occurs is very small. This indicates that the CMI model is not very useful for increasing generalizing, conjecturing, and convincing students' abilities with high PAM levels. In the group of students with high PAM levels, the specializing ability of students who obtained the CMI model had a smaller mean $\mathrm{N}$-gain than those who obtained the conventional model. This 
indicates that the CMI model is not effective at improving the specializing skills of students with high PAM levels.

Table 9. Descriptive Statistics of N-gain for Each Mathematical Thinking Indicator based on PAM

\begin{tabular}{llcccccccc}
\hline \multirow{2}{*}{$\begin{array}{l}\text { Learning } \\
\text { Factor }\end{array}$} & \multirow{2}{*}{ PAM } & \multicolumn{2}{c}{ Specializing } & \multicolumn{2}{c}{ Generalizing } & \multicolumn{2}{c}{ Conjecturing } & \multicolumn{2}{c}{ Convincing } \\
\cline { 3 - 9 } & & Mean & SD & Mean & SD & Mean & SD & Mean & SD \\
\hline CMI & Low & 0,619 & 0,103 & 0,546 & 0,249 & 0,561 & 0,214 & 0,561 & 0,214 \\
& Moderate & 0,576 & 0,248 & 0,506 & 0,342 & 0,649 & 0,185 & 0,649 & 0,185 \\
& High & 0,537 & 0,257 & 0,396 & 0,308 & 0,542 & 0,181 & 0,542 & 0,181 \\
\cline { 2 - 9 } & Total & 0,587 & 0,192 & 0,497 & 0,289 & 0,581 & 0,197 & 0,581 & 0,197 \\
\hline Conventional & Low & 0,535 & 0,098 & 0,346 & 0,030 & 0,233 & 0,224 & 0,233 & 0,224 \\
& Moderate & 0,613 & 0,108 & 0,164 & 0,356 & 0,350 & 0,202 & 0,350 & 0,202 \\
& High & 0,572 & 0,099 & 0,333 & 0,236 & 0,500 & 0,221 & 0,500 & 0,221 \\
\cline { 2 - 9 } & Total & 0,591 & 0,105 & 0,235 & 0,307 & 0,373 & 0,221 & 0,373 & 0,221 \\
\hline
\end{tabular}

Furthermore, hypothesis testing was carried out to test the significance of differences in the increase in mathematical thinking abilities of students who obtained the CMI model and those who obtained conventional models based on mathematical thinking indicators and the level of mathematical preliminary knowledge possessed by students. The prerequisite test in the form of a normality test is carried out first. The results show that there are data that are not normally distributed. Therefore, hypothesis testing was carried out using the Mann-Whitney $U$ test with a significance level of 0.05 . A summary of the test results is presented in the table 10 .

Table 10. Mann-Whitney U Test Results N-gain Score based on Mathematical Thinking Indicators and PAM

\begin{tabular}{lccccc}
\hline \multirow{2}{*}{ PAM } & \multirow{2}{*}{ Learning Model } & \multicolumn{4}{c}{ Asymp. Sig. (2-tailed) } \\
\cline { 3 - 6 } & & Specializing & Generalizing & Conjecturing & Convincing \\
\hline Low & CMI: Conventional & 0,230 & 0,017 & 0,021 & 0,021 \\
Moderate & CMI: Conventional & 0,981 & 0,018 & 0,001 & 0,001 \\
High & CMI: Conventional & 0,884 & 0,643 & 0,960 & 0,960 \\
\hline
\end{tabular}

Table 10 shows that at low and moderate PAM levels, there are significant differences in the increase in generalizing, conjecturing and convincing abilities between students who obtained the CMI model and those who obtained the conventional model. In the group of students with high PAM levels, there was no significant difference in improving mathematical thinking skills between those who obtained the CMI model and those who obtained the conventional model.

To see the interaction between learning model and PAM on improving mathematical thinking abilities, then proceed to testing the hypothesis which said that there is an interaction between learning model and PAM on improving mathematical thinking abilities. However, beforehand the prerequisite test was carried out in the form of normality and homogeneity tests. The results show that the data has a normal distribution and is also homogeneous. Therefore, hypothesis testing was carried out using the two-way ANOVA test. The results of the two-way ANOVA test are shown in the table 11. 
Table 11. The Two-Way ANOVA Test Result

\begin{tabular}{lccccc}
\hline Source & Type III Sum of Squares & Df & Mean Square & $F$ & Sig. \\
\hline Learning Factor & 0,204 & 1 & 0,204 & 12,867 & 0,001 \\
PAM & 0,002 & 2 & 0,001 & 0,066 & 0,937 \\
Interaction & 0,084 & 2 & 0,042 & 2,633 & 0,080 \\
Total & 18,574 & 66 & & & \\
\hline
\end{tabular}

In Table 11, it can be seen that the learning model sig. obtained by 0.001 , then $\mathrm{H}_{0}$ is rejected, meaning that the learning factor has a significant effect on increasing mathematical thinking abilities. However, in contrast to prior mathematical knowledge, the sig. obtained by 0.937 , then $\mathrm{H}_{0}$ is accepted, meaning that prior mathematical knowledge does not have a significant effect on improving mathematical thinking abilities. Likewise with the interaction between learning factors and prior mathematical knowledge, the sig. obtained by 0.080 , then $\mathrm{H}_{0}$ is accepted, this shows that there is no significant interaction effect between learning models and PAM on the improvement of mathematical thinking abilities. These results indicate that the effect of learning models on improving mathematical thinking abilities does not depend on the PAM category.

\section{Discussion}

Based on the result of this research, the N-gain score of students who received the CMI model and those who obtained the conventional model was different. In Table 4, it can be seen that $\mathrm{N}$-gain of students who get the CMI model is greater than students who get the conventional model. Thus, it can be concluded that the increase in mathematical thinking skills of students who get learning the CMI model is better than students who get the conventional model. Ersoy \& Güner's (2015) research found that problem solving has a positive effect on mathematical thinking abilities. The CMI model is a learning model that accommodates three stages, namely develop, solidify, and practice. At the develop stage, one of the teacher's roles is to provide open-ended mathematical questions or assignments, so that students can provide answers in several ways of solving. Indirectly, the CMI model accommodates the problem-solving process. Thus, the results of this study are in line with research conducted by Ersoy \& Güner (2015). The CMI model guides teachers in developing appropriate teaching materials as assistance for students in learning. In line with the research of Hastuti \& Marsigit (2020) which states that teaching materials developed by teachers can form good character, it is clear that the CMI model significantly provides better ability improvement than conventional models.

The significant differences in improving mathematical thinking abilities between students who get CMI model and those who get conventional models are found in generalizing, conjecturing and convincing indicators. Meanwhile, in the specializing indicator, there is no significant difference in improving mathematical thinking skills between students who get CMI model learning and those who get conventional models. These results indicate that the CMI model has a significant effect on improving every indicator of mathematical thinking ability, except specializing. This is in line with the research of Delima et al. (2021), Yildirim \& Yavuzsoy Kose (2018) and Uyangör (2019), which suggest that students in each group studied are able to specialize, in contrast to generalizing, conjecturing and convincing.

Specializing is the ability to try several problems by looking at examples. In this study, a class with a conventional model obtained a problem-based learning model. The problems given to students are problems related to specialization abilities. As stated by Setiyawan (2017), problem-based learning can develop students 'thinking skills, and 
students' thinking skills that are developed depend on the problems given. Thus, it stands to reason that the difference in specializing in increasing the ability of students who learn the CMI model and students who receive the conventional model is not significant.

The biggest difference in the $\mathrm{N}$-gain score of students who get CMI model learning and those who get conventional models occurs in the generalizing indicator. Generalizing is an aspect of mathematical thinking which is naturally owned by everyone (Delima et al., 2018). This is in line with the theory of Gestalt cognitive psychology, which states that humans have a tendency to complete or fill in incomplete experiences, in order to become more meaningful (Guberman, 2015; Hidayati, 2011). At the develop stage, students must pay attention to each answer to the question or assignment given by the teacher to see whether there is a pattern or not. In other words, students are trained to make a generalization from the answers to the questions or assignments given. Therefore, it is very reasonable that the generalizing aspects that students have are superior to other aspects.

In the student group with low PAM level, the increase in mathematical thinking skills of students who get the CMI model and those who get the conventional model is significantly different. Likewise, students with the moderate PAM level, the increase in mathematical thinking skills of students who obtained the CMI model and those who obtained the conventional model also differed significantly. Unlike students who have a high PAM level, in this group of students, there is no significant difference between the increase in mathematical thinking abilities of students who get the CMI model and those who get the conventional model. Thus, it can be concluded that the CMI model is more useful in improving the mathematical thinking abilities of students who have low and moderate prior mathematical knowledge.

It is in line with Ausebel's learning theory which states that meaningful learning occurs when students can connect new phenomena with their initial knowledge and the learning tasks given must be in accordance with the stage of students' intellectual development (Harefa, 2013). In the CMI model, every student from high, medium, and low PAM levels is given the same problem. These problems are relevant for students with low and moderate PAM, but not relevant for students with high PAM. As a result, for students with high PAM levels, there is no significant difference in the increase in mathematical thinking skills between students who get the CMI model and those who get the conventional model.

The CMI model provides a pedagogical structure for teachers to guide students in building initial ideas, strategies, and representations so that they can develop into a definition and characteristics, procedures, and models. The teacher always guides and helps students to develop in accordance with the appropriate stages of development. Intensive guidance carried out by the teacher is very effective in helping students who have low and moderate levels of initial mathematical knowledge. Meanwhile, students with a high level of initial mathematical knowledge, during the learning process, they are able to work on their own, the instructions given by the teacher are not given too much, only occasionally, when they face difficulties. The self-confidence side of students at this level is quite high, so that some students feel they do not need teacher guidance. This is why the intensity of the teacher in providing guidance to these students is quite low. As a result, the increase experienced by students at this level is not optimal.

The CMI model is only effective in increasing generalizing, conjecturing and convincing skills for students with low and moderate PAM levels. The specializing ability is the student's ability to try several questions, by looking at examples. This ability is developed in any mathematics learning with any model because learning mathematics in general will take students to solve a problem by looking at the example first. Therefore, it is clear that the increased specializing ability of students who get the CMI model is not significantly different from students who get the conventional model. 
There is no significant interaction between learning models and prior mathematical knowledge on the improvement of mathematical thinking abilities. These findings indicate that the effect of learning models on improving mathematical thinking ability does not depend on the level of prior mathematical knowledge. As shown in Table 4, in students with low and moderate prior mathematical knowledge, learning factors significantly influence the improvement of mathematical thinking skills, but this does not apply to students with high prior mathematical knowledge. The learning models has a significant influence on improving mathematical thinking abilities. However, in contrast to prior mathematical knowledge, this source does not have a significant effect on increasing mathematical thinking abilities. Likewise with the interaction between learning models and prior mathematical knowledge, the results showed that there was no significant interaction between learning models and prior mathematical knowledge on the improvement of mathematical thinking abilities. These findings indicate that the effect of learning models on improving mathematical thinking abilities does not depend on the level of prior mathematical knowledge.

\section{CONCLUSION}

Based on the research results, it can be concluded that the increase in mathematical thinking skills of students who get the CMI model is better than students who get the conventional model. The results also showed that there was no significant interaction between learning factors and students' initial knowledge of mathematics on the improvement of mathematical thinking abilities. In general, the CMI model can be applied to improve students' mathematical thinking skills. Learning with the CMI model can be applied to improve mathematical thinking skills of students with low and moderate levels of initial mathematical knowledge. In students with a high level of initial mathematical knowledge, the increase in mathematical thinking skills between classes that received CMI model and conventional learning did not differ significantly. As a result, learning with the CMI model can improve the mathematical thinking ability of each student in each category of initial mathematical knowledge, the teacher needs to design different problems according to the cognitive structure of the students' initial knowledge.

\section{ACKNOWLEDGEMENT}

The authors would like to express their gratitude to Kemenristekdikti (Ministry of research, technology, and higher education) of Indonesia for providing them Research Grant for this project

\section{REFERENCES}

Cohen, L., Manion, L., \& Morrison, K. (2007). Research Methods in Education (6th ed.). Routledge.

Delima, N. (2020). Model Comprehensive Mathematics Instruction (CMI) dalam Pembelajaran Matematika. Unsub Press. https://www.researchgate.net/publication/347561672_MODEL_COMPREHENSIV E_MATHEMATICS_INSTRUCTION_CMI_DALAM_PEMBELAJARAN_MATE MATIKA 
Delima, N., \& Fitriza, R. (2017). Pengembangan model comprehensive instruction (CMI) dalam membangun kemampuan mathematical thinking siswa. JNPM (Jurnal Nasional Pendidikan Matematika), 4(1), 1-25.

Delima, N., Kusumah, Y. S., \& Fatimah, S. (2021). Capaian kemampuan mathematical thinking siswa melalui model comprehensive mathematics instructions. Jurnal Elemen, 7(1), 146-163. https://doi.org/10.29408/jel.v7i1.2793

Delima, N., Rahmah, M. A., \& Akbar, A. (2018). The analysis of students' mathematical thinking based on their mathematics self-concept. Journal of Physics: Conference Series, 1108(1). https://doi.org/10.1088/1742-6596/1108/1/012104

Devlin, K. J. (2012). Introduction to mathematical thinking. Keith Devlin.

Ersoy, E., \& Güner, P. (2015). The place of problem solving and mathematical thinking in the mathematical teaching. The Online Journal of New Horizons in Education, 5(1), $120-130$.

Guberman, S. (2015). On Gestalt theory principles. Gestalt Theory, 37(1), 25-44.

Hake, R. R. (1999). Analyzing Change/ Gain Scores. In American Educational Association's Division D, Measurement and Research Metodology. Indiana University. http://www.physics.indiana.edu/ sdi/AnalyzingChange-Gain.pdf

Harefa, A. O. (2013). Penerapan teori pembelajaran ausebel dalam pembelajaran. Majalah Ilmiah Warta Dharmawangsa, 36, 43-55. https://media.neliti.com/media/publications/168547-ID-penerapan-teoripembelajaran-ausebel-dal.pdf

Hastuti, H. D., \& Marsigit, M. (2020). Character education application in thematicintegrative learning of curriculum 2013. Formatif: Jurnal Ilmiah Pendidikan MIPA, 10(1), 35-46. https://doi.org/10.30998/formatif.v10i1.4735

Hendrickson, S., Sutorius, J., Lemon, T., Kuehl, B., \& Honey, J. (2013). Multi-tasking Through the Common Core Using Learning Cycles. www.mathemaFcsvisionproject.org

Hidayati, T. N. (2011). Implementasi Teori belajar gestalt pada proses pembelajaran. Jurnal Falasifa, 2(1), 1-19. https://jurnalfalasifa.files.wordpress.com/2012/11/1titin-nur-hidayati-implementasi-teori-belajar-gestalt-pada-proses-pembelajaran.pdf

Kemdikbud. (2020). Penyelenggaraan Asesmen Nasional Tahun 2021. https://lpmpbabel.kemdikbud.go.id/wp-content/uploads/2021/01/AsesmenNasional.pdf

Kemendikbud. (2019). Ringkasan Eksekutif Hasil Ujian Nasional 2019 Masukan untuk Pembelajaran di Sekolah SMA/MA. https://hasilun.puspendik.kemdikbud.go.id/\#2019!sma!soal_release!02\&99\&999!s\& $\mathrm{T} \& \mathrm{~T} \& \mathrm{~T} \& 1 \& ! 1 ! \&$

Mason, J., Burton, L., \& Stacey, K. (2010). Thinking Mathematically, Second Edition (2nd ed.). Pearson. www.pearsoned.co.uk

Mason, J., \& Johnston-Wilder, S. (2004). Designing and Using Mathematical Tasks. Tarquin Press.

OECD. (2019). PISA 2018 Results. Combined Executive Summaries. OECD Publishing. www.oecd.org/about/publishing/corrigenda.htm.

Setiyawan, H. (2017). Pembelajaran matematika model PBL pada mata pelajaran matematika materi luas bidang pada siswa kelas III SD. Jurnal Inovasi, XIX(1), 1-17. https://erepository.uwks.ac.id/276/1/JURNAL_HERY_FBS.pdf

Stacey, K. (2006). What is Mathematical Thinking and Why Is It Important? https://www.researchgate.net/publication/254408829 
Uyangör, S. M. (2019). Investigation of the mathematical thinking processes of students in mathematics education supported with graph theory. Universal Journal of Educational Research, 7(1), 1-9. https://doi.org/10.13189/ujer.2019.070101

Yildirim, D., \& Yavuzsoy Kose, N. (2018). Mathematical thinking processes of secondary school students in polygon problems. Abant İzzet Baysal Üniversitesi Eğitim Fakültesi Dergisi, 18(1), 605-633. https://dergipark.org.tr/en/download/articlefile/376448 